\title{
ПРИНЦИПИ ФІЗИЧНОЇ РЕАБІЛІТАЦІЇ ХВОРИХ ІЗ ТРАВМОЮ КОЛІННОГО СУГЛОБА ПІСЛЯ ПРОВЕДЕННЯ АРТРОСКОПІЧНОГО ОПЕРАЦІЙНОГО ВТРУЧАННЯ
}

\author{
П. П. Новікова, Б. В. Дорошенко, Я. М. Кіцак \\ Медичний центр "Сучасна ортопедія" \\ Івано-Франківська обласна клінічна лікарня \\ ДВНЗ «Тернопільський державний медччний університет \\ імені І. Я. Горбачевського МОЗ Украӥни» \\ ННІ медсестринства
}

\begin{abstract}
У статті висвітлено основні принципи застосування методів фізичної реабілітації хворих із травматичним ушкодженням колінного суглоба після проведення артроскопічного втручання. Значну увагу приділено визначенню програми фізичної реабілітації, яка спрямована на зниження післяопераційних ускладнень та відновлення функціональної здатності ушкодженого суглоба.
\end{abstract}

\section{PRINCIPLES OF PHYSICAL REHABILITATION OF PATIENTS WITH KNEE JOINT TRAUMA AFTER ARTHROSCOPIC SURGERY}

\author{
P. P. Novikova, B. V. Doroshenko, Ya. M. Kitsak \\ Medical Center "Contemporary Orthopedics" \\ Ivano-Frankivsk Regional Clinical Hospital \\ I. Horbachevsky Ternopil State Medical University \\ International Nursing School
}

\begin{abstract}
The article describes main principles of physical rehabilitation methods for patients with traumatic injury of the knee joint after arthroscopic surgery. Considerable attention is paid to the definition of the program of physical rehabilitation, which is aimed to reduce postoperative complications and restore functional capacity of the injured joint.
\end{abstract}

Вступ. Частота травматичних ушкоджень колінного суглоба в структурі травм опорно-рухового апарату становить від 50 до 70 \% [2, 12]. Складна анатомічна конфігурація колінного суглоба та функціональна рухомість у трьох проекціях призводять до збільшення його травматизації. За даними авторів, серед ушкоджень зв'язкових структур суглоба провідне місце займають ушкодження хрестоподібних зв'язок та менісків $[9,11]$. Велике значення у процесах відновлення працездатності має використання прогресивних методів лікування, а саме - артроскопічних операційних втручаннях, що полягають у видаленні ушкоджених структур та реконструкцій зв'язкових структур колінного суглоба. Дані операційні втручання не лише дозволяють зберегти функціональну

(ㄷ П. П. Новікова, Б. В. Дорошенко, Я. М. Кіцак, 2018 здатність суглоба, але й попередити розвиток посттравматичного деформуючого артрозу [1, 5].

Ефективність фізичної реабілітації після проведення артроскопічного операційного втручання залежить від правильної оцінки функціональних порушень колінного суглоба, стану його структурних елементів, зокрема хряща та зв'язкового апарату, післяопераційного гемартрозу [3, 6]. Більшість функціональних порушень пов'язана з передопераційними ушкодженнями структур колінного суглоба та власне операційним втручанням із наступним обмеженням рухомості суглоба, особливостями післяопераційного періоду - репаративними процесами $[7,10]$.

Мета роботи: визначення основних аспектів застосування фізичної реабілітації після проведення артроскопічного операційного втручання хворим із 
травматичним ушкодженням колінного суглоба, а також дослідження впливу фізичної реабілітації на функціональний стан суглоба після проведення артроскопічної операції з приводу ушкодження менісків та хрестоподібних зв'язок колінного суглоба.

Основна частина. Часті ушкодження колінного суглоба пов'язані з тим, що розташовуються поверхнево, окрім того, при зафіксованій стопі і різких осьових рухах тулуба виникають розриви зв'язок суглоба та травми менісків $[2,14]$.

Після проведення артроскопічного операційного втручання актуальною залишається проблема відновлення функціональної здатності суглоба, забезпечення повної амплітуди рухів та підвищення активності атрофованих м'язів нижньої кінцівки. Значна роль у відновленні працездатності постраждалого належить фізичній реабілітації $[4,13]$.

Узагальнення даних літератури свідчить, що для відновлення повного обсягу рухів колінного суглоба в постраждалих із ушкодженням внутрішньосуглобового зв'язкового апарату та менісків необхідні затрати значного часового проміжку. Багато уваги у лікувальних установах приділяють усуненню таких проявів, як контрактура суглоба, гіпотонія м'язів та біль. На сьогодні є надзвичайно актуальним вдосконалення традиційних програм реабілітації хворих із травматичним ушкодженням колінного суглоба та розробка нових $[13,15]$.

У проведенні фізичної реабілітації базовими $\epsilon$ такі принципи:

- ранній початок виконання реабілітаційної програми;

- етапність надання реабілітаційної допомоги 3 обов'язковою мотивацією постраждалого та ґрунтовним поясненням мети лікування, яке проводиться;

- запровадження поступовості методик реабілітаційного лікування з підтвердженням їхньої ефективності;

- комплексність та співвідносність до віку та наявності супутніх захворювань;

- активне залучення хворого в процес реабілітаційного лікування;

- адекватність тривалості реабілітації.

При призначенні програми реабілітації хворому враховують:

- раннє навантаження та розробка суглоба;

- контроль набряку суглоба;

- зміцнення м'язів травмованої кінцівки.

У літературі представлена значна кількість різних засобів фізичної реабілітації після проведення артроскопічного операційного втручання з приводу розриву хрестоподібних зв'язок. Для зменшення болю використовують лід та пасивні рухи у ранній післяопераційний період. 3 7-10 днів рекомендують активні та пасивні рухи, мобілізуючі вправи. Згодом заняття на велотренажері, піднімання сходинками, ходьба та біг. Загалом програма реабілітації займає від 6 до 12 місяців [6, 8, 16, 17, 19].

Особливе місце в реабілітації, за даними П. В. Блоховітіна, займає лікування положенням. Ця процедура полягає у спеціальному укладанні нижньої кінцівки в коригуюче положення, яке здійснюється за допомогою лонгет та фіксуючих пов'язок. Дане лікування спрямоване на профілактику патологічного укладання кінцівки.

В. М. Шубкін акцентує увагу на обов'язковому застосуванні гідрокінезитерапії у реабілітаційному лікуванні хворих із травмою хрестоподібних зв'язок. Вправи виконують у воді, що, на думку автора, сприяє зниженню напруження м'язів травмованої кінцівки, збільшенню осьового навантаження і тренування опорної функції.

Цікавою на сьогодні залишається методика тривалих пасивних рухів, що розроблена американськими вченими, ефективність якої доведена як експериментально, так і клінічно.

На думку C. Edson, у комплексному реабілітаційному лікуванні необхідним є застосування пасивної механотерапії на апаратах безперервних пасивних рухів. Метою застосування даних апаратів $\epsilon$ збільшення пасивних рухів у травмованому суглобі. Методика полягає у постійно наростаючому збільшенні об'єму рухомості у суглобі за рахунок шин-дозаторів, що дозволяє швидше розсмоктатися ексудату та скоротити період реабілітації (за умов відсутності тяжких внутрішньосуглобових переломів) (рис. 1).

Ефективність полягає у підборі заданої амплітуди та швидкості пасивного згинання кінцівки за умови розслаблення мязів.

Ця методика найефективніша в ранній післятравматичний та післяопераційний періоди і повинна проводитись під прикриттям пролонгованих анестетиків (bupivacainum) з тривалістю занять до 4 тижнів для колінного суглоба $[4,12,15,18]$. Методика тривалих пасивних рухів дозволяє покращити вплив на суглобовий хрящ та періартикулярні тканини. Проте найефективніша методика при повній декомпресії суглоба.

Висновки. Своєчасне застосування засобів і методів фізичної реабілітації хворим із травматичним 


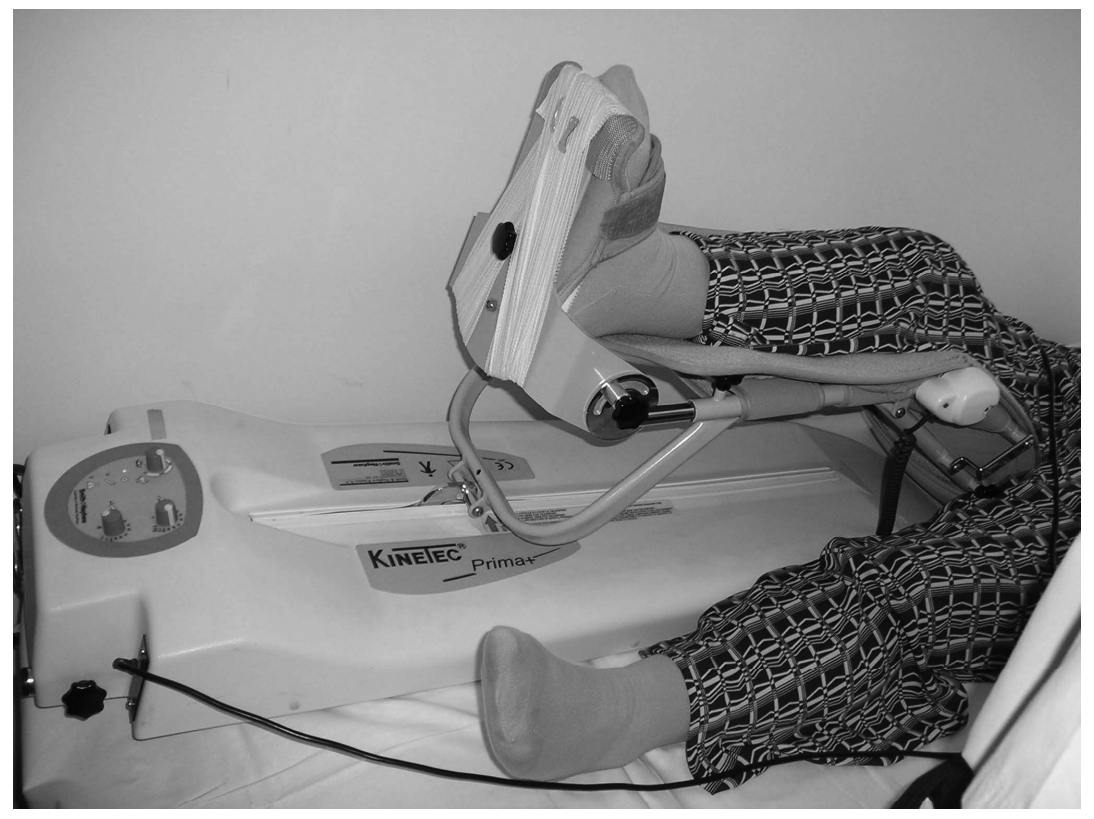

PUс. 1. Застосування методики тривалих пасивних рухів за допомогою функціональних шин-дозаторів при травмах колінного суглоба.

ушкодженням колінного суглоба, після проведення операційного артроскопічного втручання, запобігає розвитку контрактур суглоба та атрофії м'язів, а також сприяє відновленню повної амплітуди рухів колінного суглоба.

\section{СПИСОК ЛІТЕРАТУРИ}

1. Амжад А. Б. Хамдони Комплексная физическая реабилитация в лечении больных с повреждениями связок коленного сустава (обзор литературы) / Амжад А. Б. Хамдони / Слобожанський науково-спортивний вісник. - Харків : ХДАФК, 2006. - № 10. - С. 143-146.

2. Восстановление передней крестообразной связки на фоне гонартроза / М. Л. Головаха, В. Орлянский, Р.В.Титарчук, К. П. Бенедетто // Ортопедия, травматология и протезирование. - 2015. - № 1. - С. 93-101.

3. Гайко О. Г. Оцінка ефективності лікувально-реабілітаційних заходів після артроскопічних втручань у хворих з ушкодженнями менісків та передньої хрестоподібної зв'язки колінного суглоба / О. Г. Гайко, Л.В.Перфілова // 36. наукових праць XVII з'ізду ортопедів-травматологів України, Київ, 5-7 жовтня 2016 р. - К. : ДУ «ІТО НАМНУ», 2016. - С. 369-369.

4. Епифанов В. А. Реабилитация в травматологии / В. А. Епифанов, А. В. Епифанов. - М. : ГЭОТАР-Медиа, 2010. - 336 c.

5. Епифанов В. А. Восстановительное лечение при повреждениях опорно-двигательного аппарата / В. А. Епифанов, А. В. Епифанов. - М. : Авторская академия, 2009. - 479 c.
Програми фізичної реабілітації хворих із травмою колінного суглоба повинні бути спрямованими на зниження післяопераційних ускладнень, збереження функціональної активності та повного відновлення функцій оперованого суглоба.

6. Етапна реабілітація після артроскопічних втручань на колінному суглобі / І. В. Рой, О. І. Баяндіна, І. К. Бабова, О. А. Костогриз // Медична і фізична реабілітація - європейський підхід в рамках міжнародного медичного конгресу «Впровадження сучасних досягнень медичної науки в практику охорони здоров'я України» : матеріали міжнародного конгресу. - К., 2012. - С. 68.

7. Зазірний І. М. Сучасні суперечливі погляди на реабілітацію після реконструкції передньої хрестоподібної зв'язки (огляд літератури). Частина II / І. М. Зазірний // Вісник ортопедії, травматології та протезування. - 2014. № 3. - С. 75-79.

8. Изометрические упражнения с элементами постизометрической релаксации в устранении контрактур коленного сустава после артроскопической пластики передней крестообразной связки / О. В. Пилипенко, А. А. Захаров, К. А. Срибный, А. К. Никаноров // Физ. воспитание студ. - 2014. - № 2. - С. 48-52.

9. Колінний суглоб (променева анатомія, методи дослідження, променева діагностика захворювань і травматичних ушкоджень) / М. І. Спузяк, О. П. Шармазанова, Р. Я. Абдуллаєв та ін. - Донецьк : Видавець Заславський О. Ю., 2011. - 208 с. 
10. Королев А. В. Физическая реабилитация пациентов после артроскопических операций на коленном суставе / А. В. Королев // Скорая мед. помощь. - 2003. - Спец. выпуск. - С. 48.

11. Лоскутов А. Е. Медицинская реабилитация больных после артроскопии коленного сустава / А. Е. Лоскутов, М. Л. Головаха // Вісник ортопедії, травматології та протезування. - 2008. - № 4. - С. 31-35.

12. Методика відновного лікування хворих після артроскопічної реконструкції передньої хрестоподібної зв'язки в ранньому післяопераційному періоді : методичні рекомендації / уклад. І. В. Рой, С. С. Страфун, О. О. Коструб [та ін.] ; НАМНУ, МОЗУ, УЦНМІ ПЛР, ІТО НАМНУ. К . : ТОВ «Етна-1», 2015. - 28 с.

13. Мухін В. М. Фізична реабілітація в травматології : монографія / В. М. Мухін. - Л. : ЛДУФК, 2015. - 428 с.

14. Никаноров А. К. Значение предоперационного периода в восстановлении двигательной функции коленного сустава при артроскопической реконструкции передней крестообразной связки / А. К. Никаноров // Слобожанський науково-спортивний вісник. - Харків : ХДАФК, 2013. - № 2. - С. 131-133.
15. Париш Мохаммад Реза Современные аспекты физической реабилитации футболистов после повреждения капсульно-связочного аппарата коленного сустава / Париш Мохаммад Реза, А. К. Никаноров // Педагогіка, психологія та мед.-біол. пробл. фіз. виховання і спорту. 2011. - № 11. - С. 91-94.

16. Фізична реабілітація пацієнтів після артроскопічної реконструкції передньої хрестоподібної зв'язки колінного суглоба на пізньому післяопераційному періоді / О. Баяндіна, Л. Катюкова, М. Стрельник, А. Русанов, О. Ніканоров // Фіз. культура, спорт та здоров'я нації : зб. наук. пр. К., 2014. - Вип. 17. - С. 625-629.

17. Чеміріс А. Й. Фізична реабілітація хворих з пошкодженням передньої хрестоподібної зв'язки колінного суглоба / А. Й. Чеміріс, А. В. Давиденко // Літопис травматології та ортопедії. - 2011. - № 1-2. - С. 271-271.

18. Harrelson L. H. Knee rehabilitation / L. H. Harrelson // Physical rehabilitation of the injured athlete. - New York, 2001. - P. 267-343.

19. Edson C. Postoperative rehabilitation of the multipleligament reconstructed knee / C. Edson // Oper. Tech. Sports Med. - 2003. - №11. - P. 294-301. 